\title{
SWAN-GANZ CATHETER CONTAMINATION: A PROTECTIVE SLEEVE FOR REPOSITIONING
}

\author{
Michel C. Bessette, Luc Quintin, David G. Whalley and J. Earl Wynands
}

\section{ABSTRACT}

Valuable haemodynamic data can be derived from a properly positioned Swan-Ganz catheter. Unfortunately, a significant number of these catheters will, for one reason or another, become malpositioned. Withdrawing a catheter from a permanently wedged position presents little difficulty. Repositioning may, however, necessitate its advancement, with the attendant risk of bacterial contamination.

We have solved this problem by making a protective sleeve from readily available latex drain and tubing, which fits securely over the haemostatic valve of a No. 8F Cordis introducer. Iodine solution is injected into the sleeve to provide a sterile environment for the Swan-Ganz catheter, which can then be repositioned as required without the risk of bacterial contamination, as verified by bacteriological studies.

KEY WORDS: EquIPMENT, Swan-Ganz catheter, repositioning.

THE AVAILABILITY of percutaneous introducers and flow guided pulmonary artery catheters (Swan-Ganz catheters) has increased the monitoring capability of those centers equipped with facilities for perioperative invasive pressure measurements.

There are risks inherent in the use of SwanGanz catheters. ${ }^{1,2}$ We frequently insert SwanGanz catheters, and it has been our experience that a well positioned catheter may, for a number of reasons, subsequently require repositioning.

Bacterial contamination is not a problem when the catheter is withdrawn; however, contamination may occur when the catheter is advanced. Kopman et al. ${ }^{3}$ found that approximately 25 per cent of this type of catheter properly positioned preoperatively for cardiac surgery had to be repositioned because of failure to wedge. They provided a $25 \mathrm{~cm}$ sterile segment of catheter by protecting it with the sterile plastic sheath from an Intracath ${ }^{\circledast}$. The sterility of the technique was verified by cultures taken from the interior of the sheath.

Gomez et al. ${ }^{4}$ reported two series of patients in whom Swan-Ganz catheters were introduced. In the first series, an occlusive dressing provided a barrier to bacterial contamination in only 9 of 18

Michel C. Bessette, R.I.T.A.T., Chief Anaesthesia Technologist; Luc Quintin, M.D., Resident; David G. Whalley, M.B., Ch.B., Assistant Anaesthetist; J. Earl Wynands, M.D., F.R.C.P.(C), Senior Anaesthetist; Department of Anaesthesia, Royal Victoria Hospital, Montreal, Quebec.

Canad. Anaesth. Soc. J., vol. 28, no. 1, January 1981 catheters cultured. In the second series, using an isolation unit, none of the 20 catheters cultured showed contamination. The isolation unit was also made from the plastic sheath of an Intracath $^{\circledast}$. It was sutured to the skin near the site of insertion and tied over the cannula of a Cordis $8 \mathrm{~F}$ introducer. The side port extension was used to introduce an iodine solution into the plastic sheath.

We wanted to design a protective sleeve which would provide 15 to $25 \mathrm{~cm}$ of sterile Swan-Ganz catheter for any repositioning that may be required, following initial insertion. We also wanted the sleeve to attach easily over the haemostatic valve of a No. 8F Cordis introducer, so permitting the introducer cannula to be used as a central intravenous line. Finally, the sleeve had to be made from readily available material.

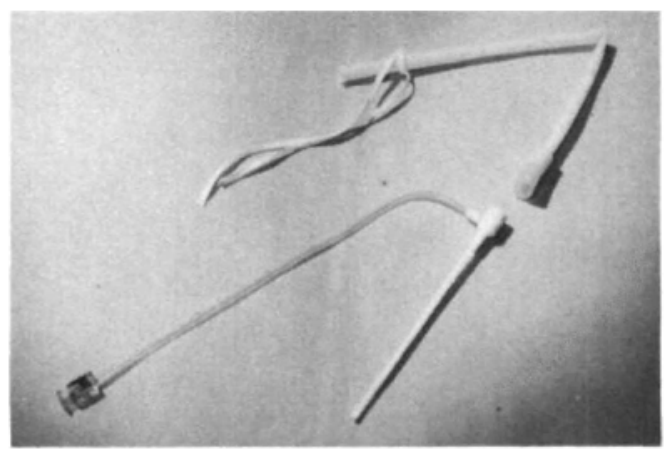

Figure 1 The component parts of the protective sleeve and Cordis introducer. 


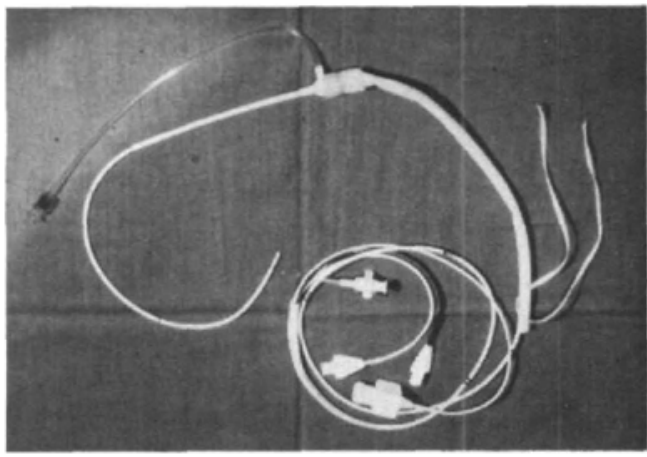

FIGURE 2 The Swan-Ganz catheter, protective sleeve and introducer assembled.

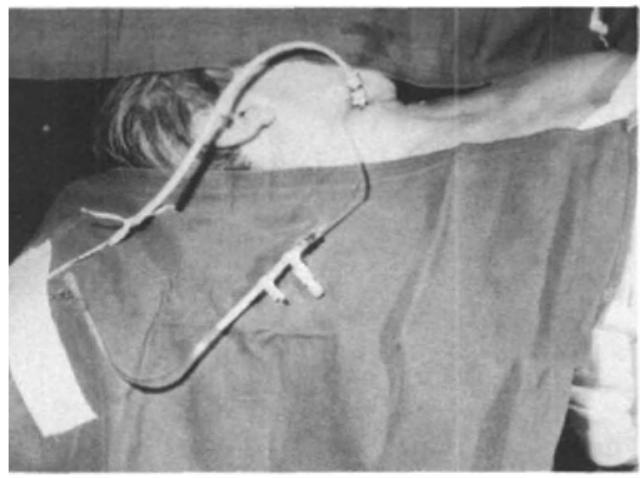

Figure 3 The Swan-Ganz catheter, protective sleeve and introducer in place in the neck of a patient.

The component parts of the Cordis introducer and the protective sleeve are shown in Figure 1. The sleeve is made from a $2 \mathrm{~cm}$ length of latex tubing ( $8 \mathrm{~mm}$ ID) to which is attached $20 \mathrm{~cm}$ of latex drain (6 mm ID). In Figure 2, the SwanGanz catheter is seen passed through the protective sleeve and the cannula of the introducer. The right internal jugular vein is catheterized, as described by Boulanger $e t a^{5}$, with a $16 \mathrm{G}$ teflon intravenous cannula. The introducer is placed in the vein, using a Seldinger technique. An intravenous infusion connected to the sidearm of the introducer is allowed to run slowly. The
Swan-Ganz catheter is threaded through the sleeve and wet with heparin (1000 units $/ \mathrm{ml}$ ) before insertion through the haemostatic valve.

When the Swan-Ganz catheter has been satisfactorily positioned in the pulmonary artery, the sleeve is advanced and the latex tube is fitted over the haemostatic valve. Movement of the cannula and sleeve is prevented by fixing both to the skin with a silk suture. Five to eight $\mathrm{cm}$ of the distal end of the latex sheath is telescoped along the Swan-Ganz catheter before it is closed with a length of cotton tie or waterproof tape. Three $\mathrm{ml}$ of povidone-iodine solution (one per cent available iodine) is injected into the sleeve by piercing the latex tube with a $22 \mathrm{G}$ needle.

Ten consecutive patients were studied to determine the effectiveness of the protective sleeve in preventing contamination of the Swan-Ganz catheter. The catheter and introducer were removed from the patient as soon as haemodynamic data were no longer required. The tip of the Swan-Ganz catheter and the interior of the $2 \mathrm{~cm}$ latex tube were subsequently swabbed and cultured. The time that the catheters remained in place ranged from 23 to 53 hours (mean 42 hours). No bacterial growth was noted at either culture site in any of the patients studied.

\section{REFERENCES}

1. SWAN, H.J.C. \& GANZ, W. Use of balloon flotation catheters in critically ill patients. Surg. Clin. North Am. 55: 501 (1975).

2. Katz, J.D., Cronau, L.H., Barash, P.G. \& MANDEL, S.D. Pulmonary artery flow-guided catheters in the perioperative period. JAMA 237: 2832 (1977).

3. Kopman, E.A. \& Sandza, J.G., JR. Manipulation of the pulmonary-artery catheter after placement: Maintenance of sterility. Anesthesiology $48: 373$ (1978)

4. Gomez, F., Spagna, P. \& Lemole, G.M. Improved techniques in using the Swan-Ganz catheter. Ann. Thorac. Surg. 27:468 (1979).

5. Boulanger, M. Delva, E., Mallle, J.G. \& PAIEMENT, B. Une nouvelle voie d'abord de la veine jugulaire interne. Canad. Anaesth. Soc. J. 23: 609 (1976).

\section{RÉSUMÉ}

Un cathêter de Swan-Ganz en bonne position fournit des informations hémodynamiques précieuses. Malheureusement, une proportion significative de ces cathéters se dẻplacent après avoir été installés de façon adéquate. Leur repositionnement peut nécessiter de les repousser plus loin dans l'artère pulmonaire, ce qui comporte un risque de contamination bactérienne. Nous avons réglế ce problème en fabriquant des manchons au moyen de drains de latex de diamètre interne de six mm et en fixant l'une des extrémités de ce drain autour d'un tube de latex de deux $\mathrm{cm}$ de longueur et de huit $\mathrm{mm}$ de diamètre interne. Ces éléments sont stérilisés et entreposés dans les paquets stériles utilisés lors de l'installation des Swan-Ganz. Après canulation de la jugulaire interne et mise en place d'un introducteur de Cordis, le Swan-Ganz est glissé dans le manchon avant son insertion dans le Cordis. Lorsqu'il est 
positionné, le tube de latex utilisé comme raccord est abouté à l'extrémité du cathéter de Cordis et fixé en position. Si par la suite il devient nécessaire de replacer le cathéter flottant, une solution iodée est injectée à travers le manchon de latex et permet la désinfection du cathéter. Des contrôles bactériologiques ont démontré l'absence de contamination des cathéters avec cette méthode. 